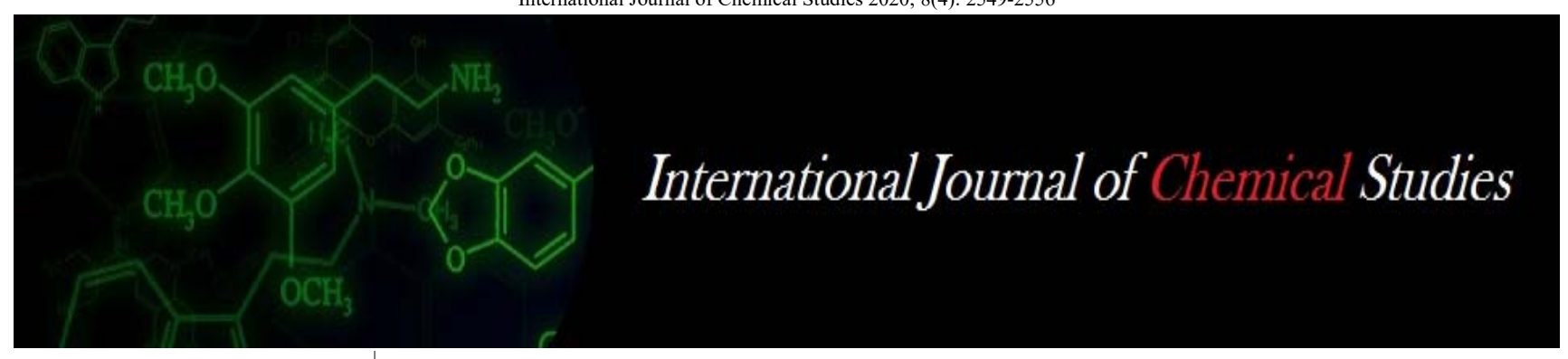

P-ISSN: 2349-8528 E-ISSN: 2321-4902 www.chemijournal.com IJCS 2020; 8(4): 2549-2556 (C) 2020 IJCS

Received: 10-05-2020

Accepted: 12-06-2020

Sukhmandeep Kaur

Department of Food and

Nutrition, Punjab Agricultural

University, Ludhiana, Punjab,

India

\section{Navjot Kaur}

Department of Food and Nutrition, Punjab Agricultural University, Ludhiana, Punjab, India

\section{Amarjeet Kaur}

Department of Food Science and Technology, Punjab Agricultural University, Ludhiana, Punjab, India
Corresponding Author: Sukhmandeep Kaur Department of Food and Nutrition, Punjab Agricultural University, Ludhiana, Punjab, India

\section{Characterization of malted cereals and legume for development of value added supplementary foods to combat malnutrition}

\author{
Sukhmandeep Kaur, Navjot Kaur and Amarjeet Kaur
}

DOI: $\underline{\text { https://doi.org/10.22271/chemi.2020.v8.i4ad.10022 }}$

\section{Abstract}

The aim of the study was to develop supplementary foods by using blends of malted wheat, mung, ragi, carrot and flaxseed powders at various proportions to avail complementary health benefits and to reduce the incidence of malnutrition to great extent. Nutritional composition of highly acceptable supplementary foods was also determined. The results of the study demonstrated that foods developed from malted cereals and legume with addition of carrots and flaxseeds powder resulted in significant improvement in the nutritional composition. Protein content was found in the range of 13.56 to 24.50 percent in experimental samples and significant increase $(p<0.05)$ in lysine content of experimental samples of dalia, khichdi, panjiri, pancakes and seviyan was found i.e. 3.39, 4.06, 3.69, 4.39 and $3.1 \mathrm{~g}$ and methionine content $1.92,2.2,1.92,1.31$ and $1.14 \mathrm{~g}$, respectively per $100 \mathrm{~g}$ protein. In vitro protein and starch digestibility was also found to be highest in experimental samples in the range of $81.25-89.82$ and 80.93-89.53 percent, respectively.

Keywords: Malting, nutritional composition, supplementary foods, cereals, malnutrition

\section{Introduction}

Malnutrition is a crucial widespread health issue in developing countries and affects a large segment of population especially children under 5 years of age. Consumption of an insufficient diet with lesser amount of calories, proteins, vitamins and minerals cause malnutrition. Decreased resistance to infection, deprived cognitive development, physical and mental retardation, fatigue, decreased physical performance, poor mental concentration and productivity are the main consequences of deficiency disorders. Children need accurate nutritional care not exclusively to promote but also to sustain their optimal health and nutritional status. Nutrition during early childhood is of vital significance as it is an establishment for life time wellbeing, strength and intellectual vitality.

Efficient supplementary feeding is beneficial in maintaining good nutritional status of malnourished children by supplementing their diets with locally available cereals and pulses based food formulations. Provision of sufficient dietary energy, macro and micro nutrients for growth and development should be the principle determinant of the growing children's diet. Locally available resources and technology appears to be the most appropriate solution to the nutritional problems of Protein Energy Malnutrition and micro nutrient deficiencies (Devi and Samundeeswari, 2013) ${ }^{[7]}$. Supplementation of locally available cereals with legumes, which are good sources of protein, will give rise to a supplementary food which is cheaper, balanced, easily digestible and acceptable to children.Various cereals and legumes are readily available and found to have nutrient potentials which could be improved by germination and complement each other if appropriately handled and blended, particularly by the rural and poor mothers during early childhood period (Bala et al., 2014) ${ }^{[4]}$. Germination has been claimed to improve the nutritive quality of cereals and has been used for centuries for the purpose of softening the kernel structure, improving its nutritional value and reducing anti-nutritional effects. The prime objective of germination is to promote the development of hydrolytic enzymes that are inactive in raw seeds (Singh et al., 2015) ${ }^{[20]}$.

Germination helps to enhance the nutritional quality of several grains such as vitamin B complex, total sugars, protein, lysine and digestibility of starch, enhances the activity of 
hydrolytic enzymes (lipase) and decrease in phytates (Dipnaik and Bathere, 2017) ${ }^{[9]}$. Lately, products from sprouted grains have emerged as a new addition to the food industry, owing to their improved nutritional value and absorption. Germinated grain products have been reported to have a superior taste and are softer and sweeter. During grain germination improved availability of reducing sugars, free amino acids including lysine and $\gamma$-aminobutyric acid (GABA) (Ding et al., 2016) ${ }^{[8]}$, soluble dietary fiber, bio-accessible minerals, phenolic compounds and antioxidant capability have been noticed. Thus, the present work aims to develop supplementary foods from locally available raw materials like wheat, mung, ragi, carrots and flaxseeds. Malting at household level is easy to handle and provide highly nutritious foods with no additional costs.

\section{Material and Methods}

The present study was conducted in the laboratories of Department of Food and Nutrition, College of Community Science, Punjab Agricultural University, Ludhiana.

Procurement of raw material: Wheat and mung were procured from Seed Technology Center of Punjab Agricultural University, Ludhiana. Ragi, carrots and flaxseeds were procured from the local market of Ludhiana.

Preparation of malted samples: Wheat, mung and ragi grains were sorted, cleaned and soaked in water and then kept for germination at room temperature. Germinated grains were then dried in hot air dryer at $60{ }^{\circ} \mathrm{C}$ for 24 hours and milled to fine flours.

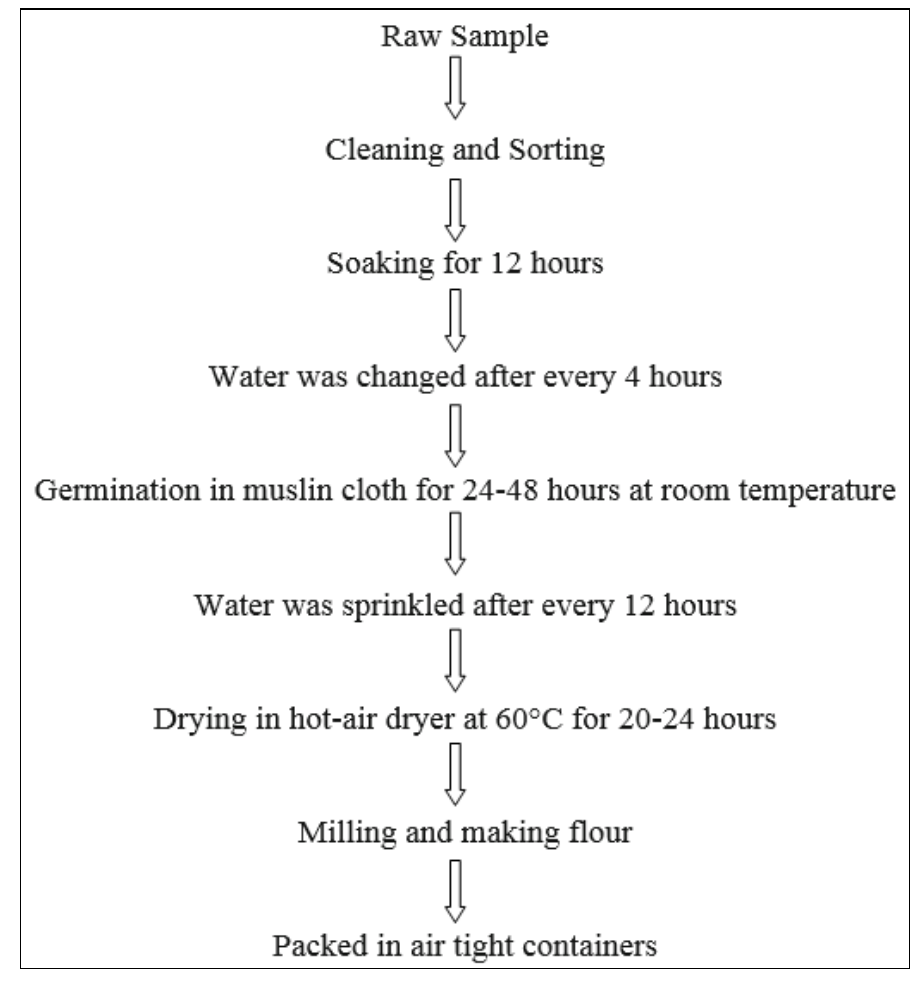

Flow Diagram for malting of grains

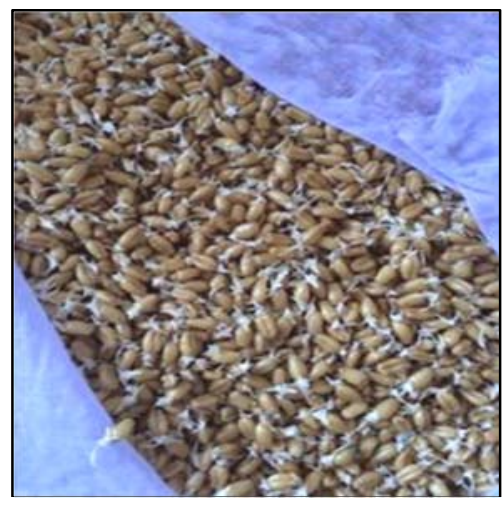

Malted wheat

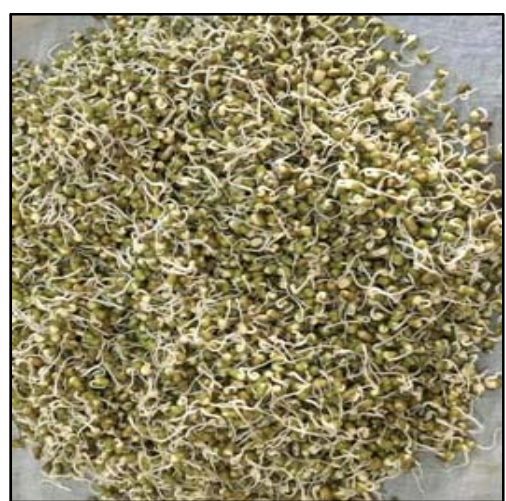

Malted mung 


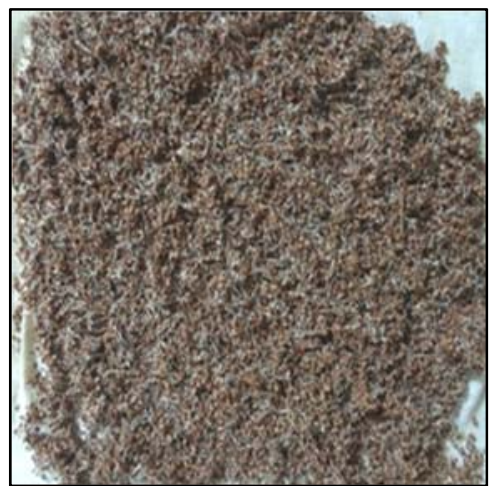

Malted ragi

Preparation of carrots and flaxseeds powder

Carrots were washed under tap water to remove dirt, then cut into slices of $1 \mathrm{~cm}$ thickness and blanched in hot water containing 1 percent sodium metabisulphite for 3 minutes.
Then, carrot slices were spread on trays and placed in hot-air dryer at $60{ }^{\circ} \mathrm{C}$ for 10 hours. After drying, the fine powder was obtained.

The flaxseeds were sorted and roasted for 5-7 minutes till they started to crackle and then cooled down and ground to get fine powder.

\section{Development of supplementary foods}

Five supplementary foods named Dalia, Khichdi, Panjiri, Pancakes and Seviyan were developed by using different ratios of raw materials. Four experimental samples for each food were developed by using different proportions of flours along with two control samples. Organoleptic evaluation was conducted to ascertain the acceptability of experimental samples and highly acceptable products were then nutritionally analyzed.

Dalia

Table 1: Ingredients and preparation method for development of dalia

\begin{tabular}{|c|c|c|c|c|c|c|}
\hline Levels (\%) & Raw wheat (g) & Malted wheat (g) & Malted mung (g) & Malted ragi (g) & Carrots powder (g) & Flaxseeds powder (g) \\
\hline C1 & 100 & - & - & - & - & - \\
\hline C2 & - & 100 & - & - & - & - \\
\hline E1 & - & 70 & 12.5 & 12.5 & 2.5 & 2.5 \\
\hline E2 & - & 70 & 10 & 10 & 5 & 5 \\
\hline E3 & - & 70 & 7.5 & 7.5 & 7.5 & 7.5 \\
\hline E4 & - & 70 & 5 & 5 & 10 & 10 \\
\hline
\end{tabular}

\section{Method}

1. Dry roast all the grains (wheat, mung, ragi) in a pan.

2. After roasting, add carrots and flaxseeds powder into them.
3. Then add water $(500 \mathrm{ml})$, salt and pepper according to taste and stir well to prevent lumps.

4. Cook dalia for 20-25 minutes on a medium flame to get a desirable consistency.

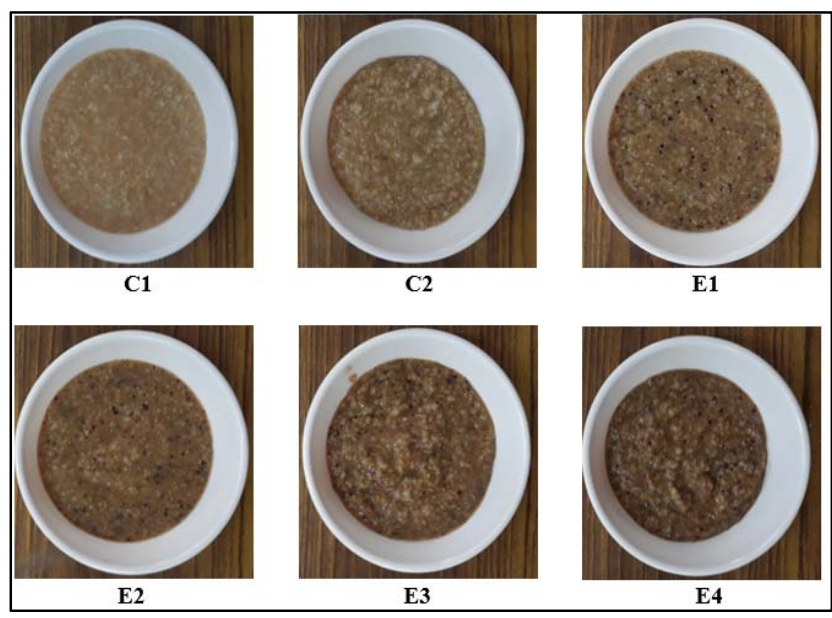

\section{Khichdi}

Table 2: Ingredients and preparation method for development of khichdi

\begin{tabular}{|c|c|c|c|c|c|c|c|}
\hline Levels (\%) & Rice (g) & Malted wheat (g) & Malted ragi (g) & Split mung (g) & Malted mung (g) & Carrots powder (g) & Flaxseeds powder (g) \\
\hline C1 & 50 & - & - & 50 & - & - & - \\
\hline C2 & 50 & - & - & - & 50 & - & - \\
\hline E1 & 45 & 2.5 & 2.5 & - & 45 & 2.5 & 2.5 \\
\hline E2 & 40 & 5 & 5 & - & 40 & 5 & 5 \\
\hline E3 & 35 & 7.5 & 7.5 & - & 35 & 7.5 & 7.5 \\
\hline E4 & 30 & 10 & 10 & - & 30 & 10 & 10 \\
\hline
\end{tabular}

\section{Method}

1. Wash rice and mung dal and soak them together in warm water for 30 minutes.
2. Heat a pan with ghee $(30 \mathrm{~g})$. Add cumin seeds (1 tsp.) and let them crackle.

3. Saute chopped onions and tomatoes in it. 
4. Add salt, chilli and turmeric powder along with malted wheat, ragi, carrots and flaxseeds powder.

5. Then add soaked rice, mung dal with water $(500 \mathrm{ml}$.) and pressure cooked for 20 minutes.

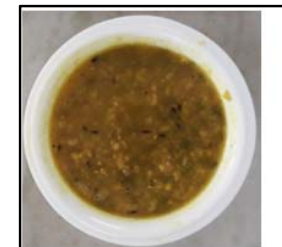

C1

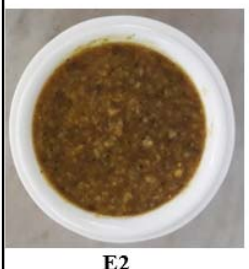

E2

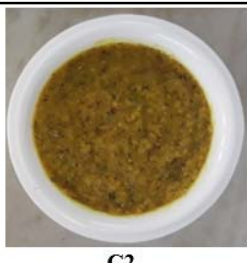

C2

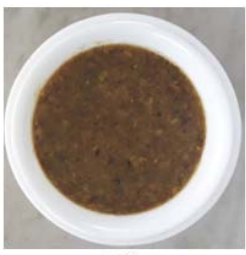

E3

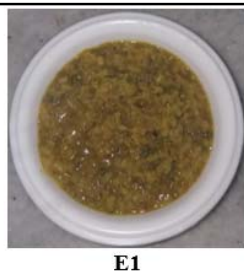

E1

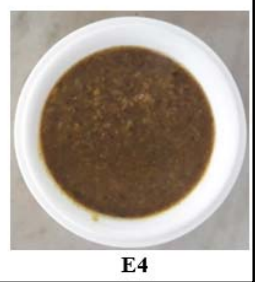

E4

Panjiri:

Table 3: Ingredients and preparation method for development of panjiri

\begin{tabular}{|c|c|c|c|c|c|c|}
\hline $\begin{array}{c}\text { Levels } \\
(\%)\end{array}$ & $\begin{array}{c}\text { Raw } \\
\text { wheat (g) }\end{array}$ & $\begin{array}{c}\text { Malted } \\
\text { wheat } \\
(\mathbf{g})\end{array}$ & $\begin{array}{c}\text { Malted } \\
\text { mung } \\
(\mathbf{g})\end{array}$ & $\begin{array}{c}\text { Malted } \\
\text { ragi (g) }\end{array}$ & $\begin{array}{c}\text { Carrots } \\
\text { powder } \\
(\mathbf{g})\end{array}$ & $\begin{array}{c}\text { Flaxseeds } \\
\text { powder (g) }\end{array}$ \\
\hline C1 & 100 & - & - & - & - & - \\
\hline C2 & - & 100 & - & - & - & - \\
\hline E1 & - & 90 & 5 & 0.5 & 2 & 2.5 \\
\hline E2 & - & 80 & 10 & 1 & 4 & 5 \\
\hline E3 & - & 70 & 15 & 1.5 & 6 & 7.5 \\
\hline E4 & - & 60 & 20 & 2 & 8 & 10 \\
\hline
\end{tabular}

\section{Method:}

1. Roast raw/malted wheat, mung and ragi flour in ghee $(50$ g).

2. Add carrots and flaxseeds powder and mix well.

3. Remove from flame and let them cool down.

4. Then add sugar (40\%), mix well and serve.

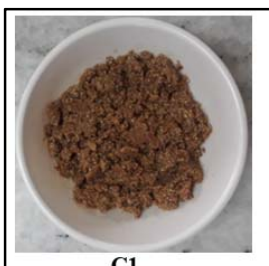

C1

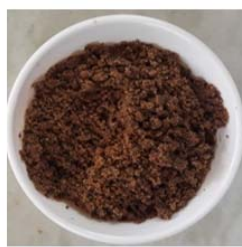

E2

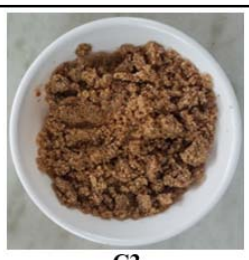

C2

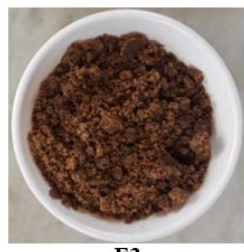

E3

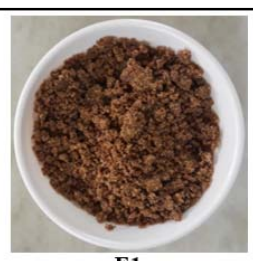

E1

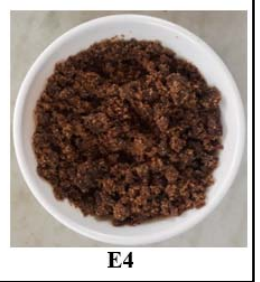

\section{Pancakes}

Table 4: Ingredients and preparation method for development of pancakes

\begin{tabular}{|c|c|c|c|c|c|c|}
\hline $\begin{array}{c}\text { Levels } \\
\mathbf{( \% )}\end{array}$ & $\begin{array}{c}\text { Mung } \\
\text { (g) }\end{array}$ & $\begin{array}{c}\text { Malted } \\
\text { mung (g) }\end{array}$ & $\begin{array}{c}\text { Malted } \\
\text { wheat (g) }\end{array}$ & $\begin{array}{c}\text { Malted } \\
\text { ragi (g) }\end{array}$ & $\begin{array}{c}\text { Carrots } \\
\text { powder } \\
\text { (g) }\end{array}$ & $\begin{array}{c}\text { Flaxseeds } \\
\text { powder (g) }\end{array}$ \\
\hline C1 & 100 & - & - & - & - & - \\
\hline C2 & - & 100 & - & - & - & - \\
\hline E1 & - & 90 & 5 & 1 & 2 & 2 \\
\hline E2 & - & 80 & 10 & 2 & 4 & 4 \\
\hline E3 & - & 70 & 15 & 3 & 6 & 6 \\
\hline E4 & - & 60 & 20 & 4 & 8 & 8 \\
\hline
\end{tabular}

\section{Method}

1. Soak grains in water for 3-4 hours.

2. Grind soaked grains and blend with water to make a smooth and lump free batter.

3. Add carrots and flaxseeds powders and mix well.

4. Mix all the spices and allow the batter to rest for $15-20$ minutes.

5. Make batter of pouring consistency and then make pancakes on pre-heated griddle.

6. Cook pancakes from both sides on medium heat by flipping both sides.

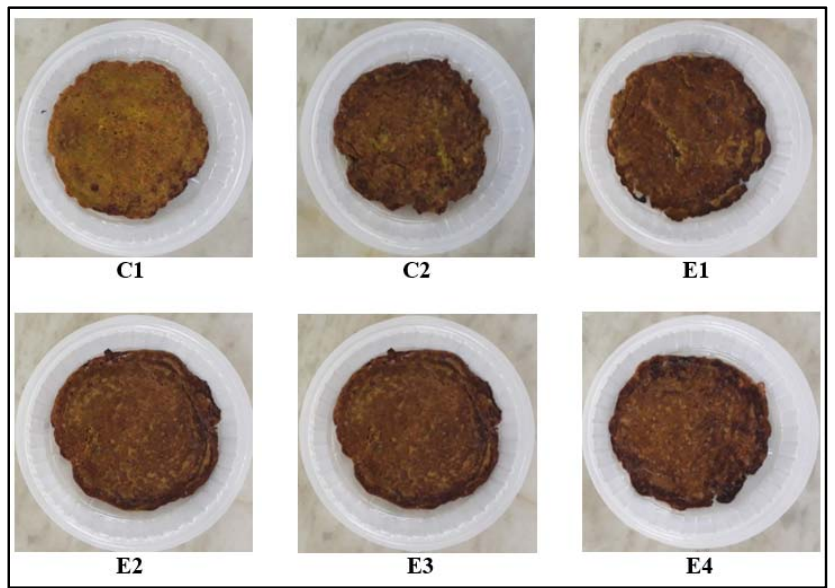

\section{Seviyan}

Table 5: Ingredients and preparation method for development of seviyan

\begin{tabular}{|c|c|c|c|c|c|c|}
\hline $\begin{array}{c}\text { Levels } \\
\mathbf{( \% )}\end{array}$ & $\begin{array}{c}\text { Besan } \\
\mathbf{( g )}\end{array}$ & $\begin{array}{c}\text { Malted } \\
\text { mung (g) }\end{array}$ & $\begin{array}{c}\text { Malted } \\
\text { wheat } \\
\mathbf{( g )}\end{array}$ & $\begin{array}{c}\text { Malted } \\
\text { ragi (g) }\end{array}$ & $\begin{array}{c}\text { Carrots } \\
\text { powder } \\
\mathbf{( g )}\end{array}$ & $\begin{array}{c}\text { Flaxseeds } \\
\text { powder (g) }\end{array}$ \\
\hline C1 & 100 & - & - & - & - & - \\
\hline C2 & 50 & 50 & - & - & - & - \\
\hline E1 & 90 & 2.5 & 2.5 & 1 & 2 & 2 \\
\hline E2 & 80 & 5 & 5 & 2 & 4 & 4 \\
\hline E3 & 70 & 7.5 & 7.5 & 3 & 6 & 6 \\
\hline E4 & 60 & 10 & 10 & 4 & 8 & 8 \\
\hline
\end{tabular}




\section{Method}

1. Mix all the flours and add salt and ajwain.

2. Add oil (10 g) and mix well

3. Prepare soft and smooth dough by adding water.

4. Knead dough and allow for rest about 15 minutes.

5. Grease seviyan maker and place dough in it.

6. Make seviyan and fry until they turned golden brown in colour.

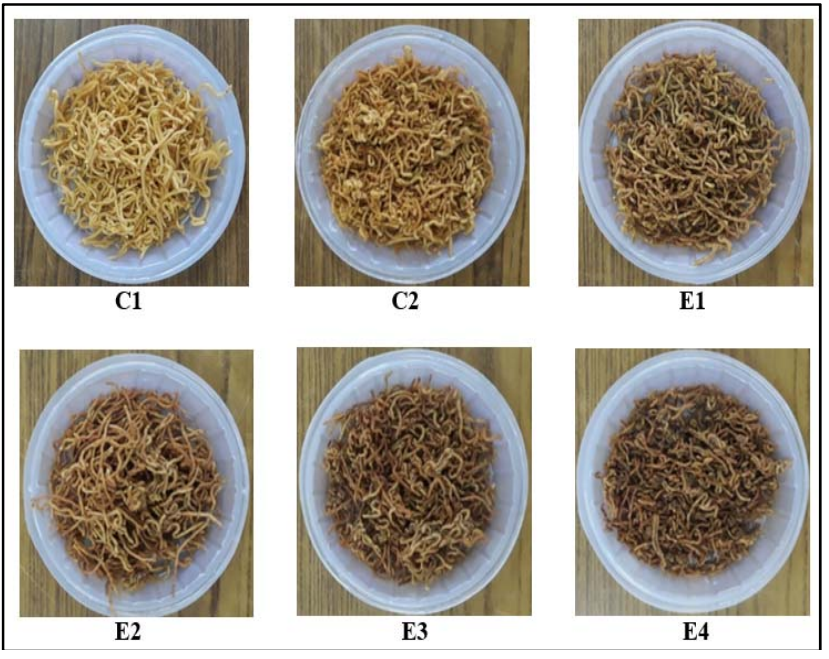

Nutritional analysis of the developed supplementary foods

The highly acceptable supplementary foods along with their control samples were analyzed for proximate composition i.e. moisture, crude protein, crude fat, crude fiber, total ash, carbohydrates and energy by using standard methods given by AOAC, (2000) ${ }^{[2]}$. Amino acids viz. lysine and methionine were estimated by using standard procedures given by Booth, (1971) ${ }^{[6]}$ and Horn et al., (1946) ${ }^{[11]}$, respectively. In-vitro protein digestibility (Akeson and Stachman, 1964) ${ }^{[1]}$, starch digestibility (Singh et al., 1982) ${ }^{[21]}$, total phenols (Singleton et al., 1999) ${ }^{[22]}$ and phytin phosphorus (Haug and Lantzsch, $1983)^{[10]}$ content was also estimated using standard methods.

\section{Statistical analysis}

The experiments were performed in three replications of each sample. Mean and standard error for different parameters were calculated. One-way analysis of variance (ANOVA) was used to study significant variation in developed supplementary foods. Comparisons between means were done by Tukey's test at the $\mathrm{p} \leq 0.05$ significance level. Statistical analysis was carried out with the SPSS software.

\section{Results and Discussion \\ Proximate composition}

The moisture content of acceptable supplementary foods of dalia, khichdi, panjiri, pancakes and seviyan were found to be significantly increased i.e. 12.36, 11.66, 4.40, 12.65 and 4.38 percent (Table 6). Protein content was found to be increased with the significant difference $(p<0.05)$ and ranged between 13.56 to 24.50 percent followed by (C2) control samples. Significant increase $(p<0.05)$ was found in ash i.e. 1.86, 2.07, $1.66,3.65$ and 3.43 percent in experimental samples of dalia, khichdi, panjiri, pancakes and seviyan, respectively. Crude fiber content was also observed to be significantly increased in all experimental samples as compared to their control samples and decreased fat in (C2) control samples with malted flours was observed. Similar findings were also reported by Kavitha and Parimalavalli, (2014) ${ }^{[14]}$, Aziah et al., (2012) ${ }^{[3]}$ and Pasha et al., (2011) ${ }^{[18]}$. Sadawarte et al., (2018) ${ }^{[19]}$ explained the reason that an increase in protein content might be due to biosynthesis of protein as a result of germination. During germination, the endogenous enzymes of the legumes were activated. Kayembe and Rensburg, (2013) ${ }^{[15]}$ and Onwurafor et al., (2020) ${ }^{[17]}$ reported the decreased fat content in germinated grains. The carbohydrate content of experimental and control samples (C2) showed significant decrease $(p<0.05)$ after malting than that of raw samples. The reason for decreased carbohydrate content might be triggered enzymatic activity in germinating seeds, leading to the catabolism of carbohydrates that could be simply destroyed during milling. Hung et al., (2011) ${ }^{[12]}$ and Steve, (2012) ${ }^{[23]}$ also reported a decrease in carbohydrates with germination.

Table 6: Proximate composition of malted grains based supplementary foods

\begin{tabular}{|c|c|c|c|c|c|c|c|c|}
\hline Products & Samples & Moisture (\%) & Crude Protein (\%) & Crude Fat (\%) & Total Ash (\%) & Crude Fibre (\%) & CHO (\%) & Energy (Kcal/100g) \\
\hline \multirow[t]{3}{*}{ Dalia } & $\mathrm{C} 1$ & $11.00^{\mathrm{b}} \pm 0.58$ & $12.69^{\mathrm{c}} \pm 0.05$ & $1.38^{\mathrm{b}} \pm 0.006$ & $1.64^{\mathrm{b}} \pm 0.005$ & $1.40^{\mathrm{b}} \pm 0.05$ & $71.89^{\mathrm{a}} \pm 0.005$ & $350.74^{\mathrm{a}} \pm 0.006$ \\
\hline & $\mathrm{C} 2$ & $13.64^{\mathrm{a}} \pm 0.06$ & $13.56^{\mathrm{b}} \pm 0.05$ & $1.26^{\mathrm{c}} \pm 0.006$ & $1.58^{\mathrm{c}} \pm 0.005$ & $1.48^{\mathrm{b}} \pm 0.006$ & $68.48^{\mathrm{b}} \pm 0.005$ & $339.50^{c} \pm 0.05$ \\
\hline & E1 & $12.36^{\mathrm{ab}} \pm 0.06$ & $15.31^{\mathrm{a}} \pm 0.05$ & $2.04^{\mathrm{a}} \pm 0.006$ & $1.86^{\mathrm{a}} \pm 0.005$ & $1.86^{\mathrm{a}} \pm 0.006$ & $66.57^{c} \pm 0.005$ & $345.88^{\mathrm{b}} \pm 0.006$ \\
\hline \multirow[t]{3}{*}{ Khichdi } & $\mathrm{C} 1$ & $11.13^{\mathrm{c}} \pm 0.005$ & $20.13^{c} \pm 0.006$ & $12.40^{\mathrm{c}} \pm 0.06$ & $1.84^{\mathrm{c}} \pm 0.01$ & $3.24^{\mathrm{c}} \pm 0.006$ & $51.26^{\mathrm{a}} \pm 0.57$ & $397.16^{\mathrm{b}} \pm 0.005$ \\
\hline & $\mathrm{C} 2$ & $13.28^{\mathrm{a}} \pm 0.05$ & $21.87^{b} \pm 0.006$ & $11.72^{b} \pm 0.005$ & $1.78^{\mathrm{b}} \pm 0.01$ & $3.42^{\mathrm{b}} \pm 0.005$ & $47.93^{\mathrm{b}} \pm 0.005$ & $384.68^{\mathrm{c}} \pm 0.005$ \\
\hline & E1 & $11.66^{\mathrm{b}} \pm 0.005$ & $23.67^{\mathrm{a}} \pm 0.006$ & $14.14^{\mathrm{a}} \pm 0.005$ & $2.07^{\mathrm{a}} \pm 0.01$ & $3.88^{\mathrm{a}} \pm 0.006$ & $44.58^{\mathrm{c}} \pm 0.06$ & $400.26^{\mathrm{a}} \pm 0.006$ \\
\hline \multirow[t]{3}{*}{ Panjiri } & $\mathrm{C} 1$ & $4.04^{\mathrm{c}} \pm 0.005$ & $12.69^{c} \pm 0.005$ & $21.54^{\mathrm{b}} \pm 0.006$ & $1.60^{\mathrm{a}} \pm 0.06$ & $1.38^{\mathrm{c}} \pm 0.006$ & $58.75^{\mathrm{a}} \pm 0.05$ & $479.62^{\mathrm{a}} \pm 0.005$ \\
\hline & $\mathrm{C} 2$ & $4.81^{\mathrm{a}} \pm 0.005$ & $13.13^{\mathrm{b}} \pm 0.005$ & $21.16^{\mathrm{c}} \pm 0.006$ & $1.44^{\mathrm{b}} \pm 0.01$ & $1.52^{\mathrm{b}} \pm 0.006$ & $57.94^{\mathrm{a}} \pm 0.57$ & $474.72^{\mathrm{b}} \pm 0.005$ \\
\hline & E1 & $4.40^{\mathrm{b}} \pm 0.06$ & $13.56^{\mathrm{a}} \pm 0.005$ & $22.56^{\mathrm{a}} \pm 0.006$ & $1.66^{\mathrm{a}} \pm 0.01$ & $2.24^{\mathrm{a}} \pm 0.006$ & $55.58^{\mathrm{b}} \pm 0.05$ & $479.60^{\mathrm{a}} \pm 0.06$ \\
\hline \multirow[t]{3}{*}{ Pancakes } & $\mathrm{C} 1$ & $12.05^{b} \pm 0.005$ & $23.23^{\mathrm{c}} \pm 0.005$ & $15.02^{b} \pm 0.005$ & $3.46^{\mathrm{b}} \pm 0.006$ & $1.92^{\mathrm{c}} \pm 0.005$ & $44.32^{\mathrm{a}} \pm 0.06$ & $405.38^{\mathrm{a}} \pm 0.005$ \\
\hline & $\mathrm{C} 2$ & $13.86^{\mathrm{a}} \pm 0.05$ & $23.62^{b} \pm 0.005$ & $14.86^{\mathrm{c}} \pm 0.005$ & $3.34^{\mathrm{c}} \pm 0.005$ & $2.20^{\mathrm{b}} \pm 0.05$ & $42.12^{\mathrm{b}} \pm 0.06$ & $396.70^{c} \pm 0.05$ \\
\hline & E2 & $12.65^{\mathrm{ab}} \pm 0.57$ & $24.50^{\mathrm{a}} \pm 0.05$ & $15.46^{\mathrm{a}} \pm 0.005$ & $3.65^{\mathrm{a}} \pm 0.005$ & $2.86^{\mathrm{a}} \pm 0.005$ & $40.88^{\mathrm{c}} \pm 0.006$ & $400.66^{\mathrm{b}} \pm 0.005$ \\
\hline \multirow[t]{3}{*}{ Seviyan } & $\mathrm{C} 1$ & $3.52^{\mathrm{c}} \pm 0.005$ & $19.25^{\mathrm{c}} \pm 0.006$ & $24.30^{\mathrm{b}} \pm 0.05$ & $2.69^{b} \pm 0.005$ & $2.60^{\mathrm{c}} \pm 0.05$ & $47.64^{\mathrm{a}} \pm 0.06$ & $486.26^{\mathrm{a}} \pm 0.05$ \\
\hline & $\mathrm{C} 2$ & $5.38^{\mathrm{a}} \pm 0.006$ & $21.87^{b} \pm 0.005$ & $22.46^{\mathrm{c}} \pm 0.005$ & $2.45^{\mathrm{c}} \pm 0.005$ & $2.92^{\mathrm{b}} \pm 0.005$ & $44.92^{\mathrm{b}} \pm 0.57$ & $469.30^{\mathrm{c}} \pm 0.05$ \\
\hline & E2 & $4.38^{b} \pm 0.005$ & $22.31^{\mathrm{a}} \pm 0.005$ & $24.48^{\mathrm{a}} \pm 0.006$ & $3.43^{\mathrm{a}} \pm 0.005$ & $3.26^{\mathrm{a}} \pm 0.006$ & $42.14^{\mathrm{c}} \pm 0.05$ & $478.12^{\mathrm{b}} \pm 0.005$ \\
\hline
\end{tabular}

Values are expressed as Mean $\pm \mathrm{SE}$

Means with different notation $(\mathrm{a}, \mathrm{b}$ and $\mathrm{c}$ ) indicates significant difference at $5 \%$ level of significance.

\section{Amino acids}

Malting positively affects the essential amino acids content of the supplementary foods. The data depicted in the Fig. 1 and 2 demonstrated the increased amino acids content in experimental samples as compared to their control samples.
The most important physiological processes associated with the germination phase are the synthesis of amylases, proteases and other endogenous hydrolytic enzymes. During the process, the hydrolytic enzymes migrate from the germ into the endosperm where starch and protein are hydrolyzed to 
sugars and amino acids, respectively. Proteolytic enzymes improve amino acid availability, particularly lysine, methionine and tryptophan that are lacking in cereals (Baranwal, 2017) ${ }^{[5]}$. The quality of protein is mainly a function of its essential amino acids. Amino acids content was found to be increased in the experimental samples ranging from 3.10 to $4.39 \mathrm{~g} / 100 \mathrm{~g}$ for lysine and 1.14 to $2.20 \mathrm{~g} / 100 \mathrm{~g}$ for methionine followed by malted control samples with the values for lysine and methionine ranging between 3.12-4.15 $\mathrm{g} / 100 \mathrm{~g}$ and $0.87-2.03 \mathrm{~g} / 100 \mathrm{~g}$, respectively.

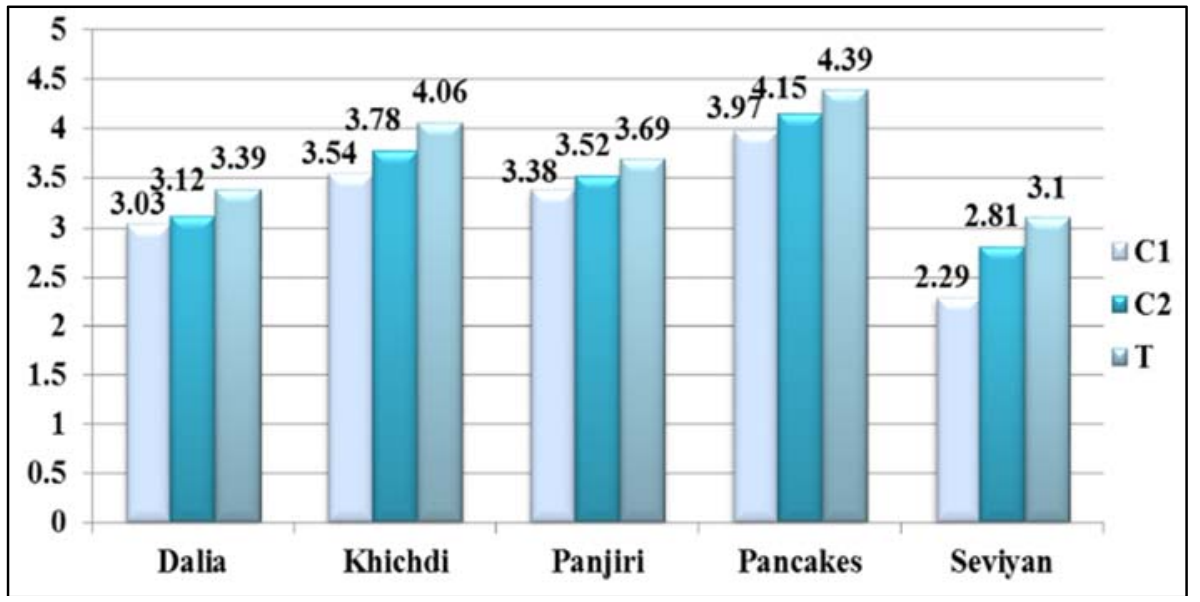

Fig 1: Available lysine content of malted grains based supplementary foods

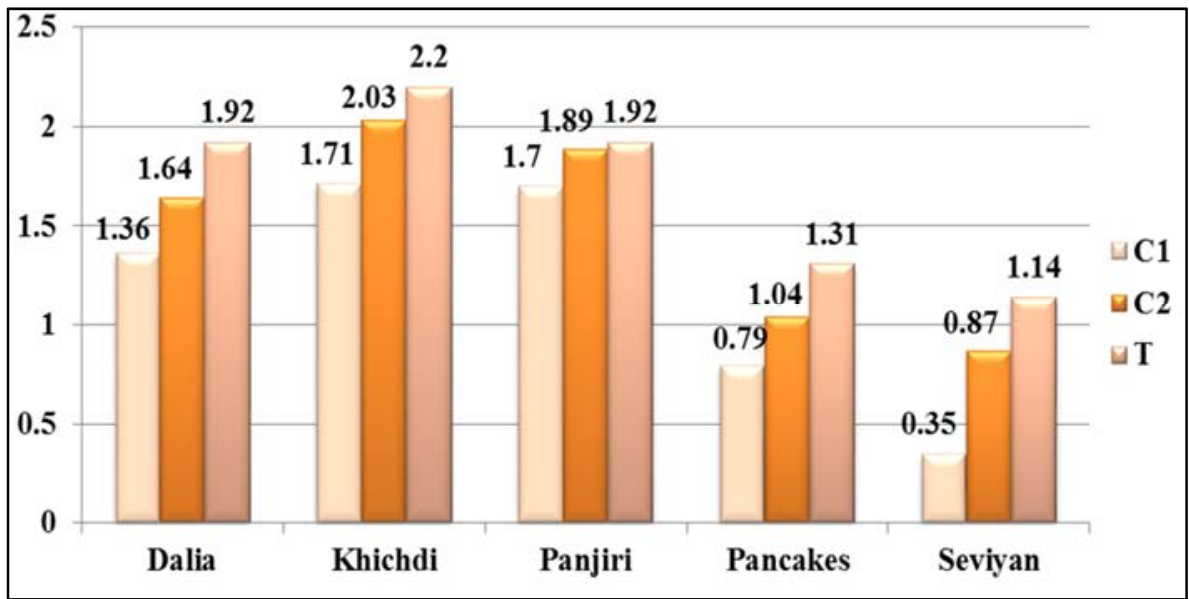

Fig. 2: Methionine content of malted grains based supplementary foods

\section{In-vitro protein and starch digestibility}

In-vitro protein and starch digestibility of products developed by using malted grains along with carrot and flaxseed powder at various proportions is depicted in Fig. 3 and 4. In-vitro digestibility is very crucial parameter in analyzing the quality of food product and assimilation of nutrients in the body. It also helps to predict the effect of any processing method on the developed food products. All the experimental samples were found to have significantly $(p<0.05)$ increased in-vitro protein and starch digestibility. The percent increase in invitro protein digestibility of experimental samples was observed in the range of 15.81-37.66 percent as compared to C1 samples of developed supplementary foods and 4.09-10.16 percent as compared to $\mathrm{C} 2$ samples. In-vitro starch digestibility content was found to be increased in the experimental samples with the values of $15.14,6.68,19.87$, 10.50 and 11.35 percent as compared to (C1) control samples, respectively.
Nelson et al., (2013) ${ }^{[16]}$ explained that protease synthesis is initiated by the activation of proenzymes as well as de novo enzyme synthesis. Storage proteins in germinating seeds undergo limited proteolysis by the action of endopeptidases to induce conformational changes that subsequently facilitate further breakdown by both endo- and exopeptidases. Complete storage protein degradation is facilitated by the activity of endo-, carboxy-, amino-, and dipeptidases where the resulting constituent amino acids support the seed's metabolic requirements. Starch is the primary reserve of nutrients in seeds and serves as a major source of calories in human diets. Approximately 80 percent of the wheat endosperm is composed of starch. The germination process activates $\alpha$-amylase, which hydrolyzes the polysaccharide starch components amylose and amylopectin into energy available sugars (Johnston et al., 2019) ${ }^{[13]}$. 


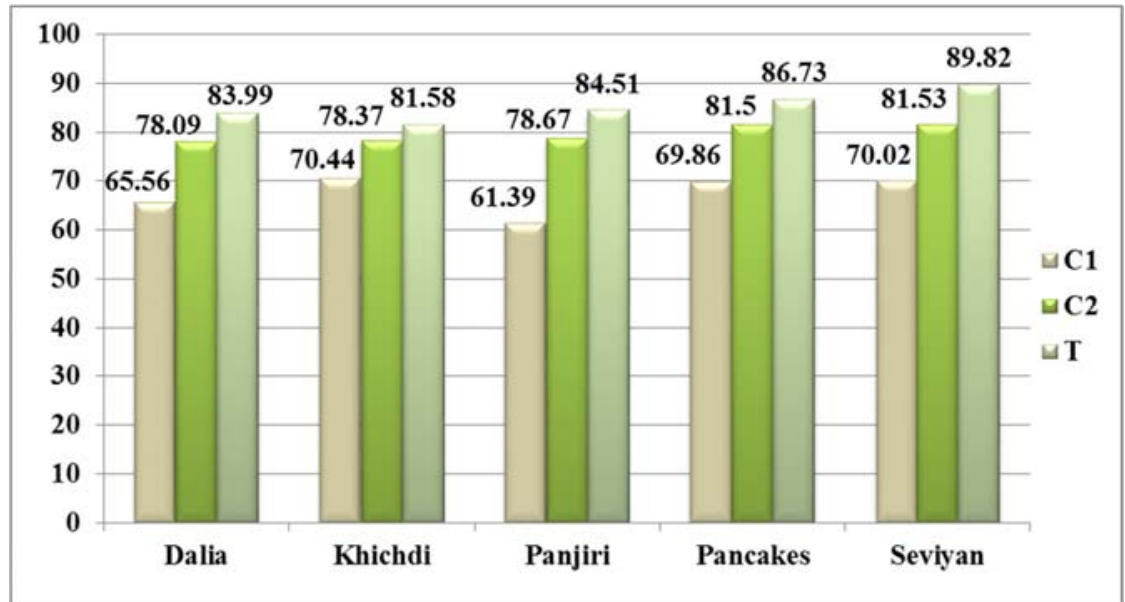

Fig 3: In-vitro protein digestibility of malted grains based supplementary foods

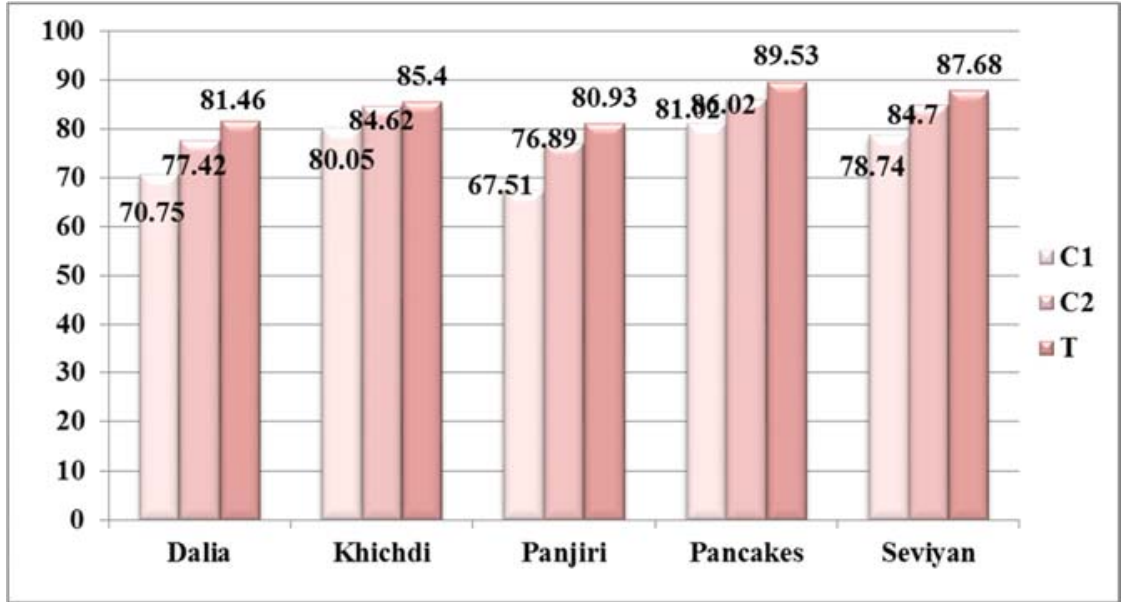

Fig 4: In-vitro starch digestibility of malted grains based supplementary foods

\section{Total Phenols and Phytin Phosphorus}

The data regarding the effect of malting on the total phenol and phytin phosphorus content of developed foods along with their control samples is given in Table 7 which reveals that there was significant $(p<0.05)$ increase in total phenols and the content of phytin phosphorus decreased on malting. The highest total phenols content was observed in experimental sample of pancakes with the value of 328.71 followed by khichdi, dalia, seviyan and panjiri with the values of 309.35 , 292.82, 279.13 and 273.46 mg GAE/100g, respectively.

Phytin phosphorus combines with nutrients and decreases their bioavailability before they are being absorbed and also affects digestive enzymes. The phytin phosphorus content was found to be significantly $(p<0.05)$ decreased in malted grains based products. The highest values were found in control samples prepared with raw or unprocessed flours ranging between $262.04-348.40 \mathrm{mg} / 100 \mathrm{~g}$ and in experimental samples of all the products it was observed to be significantly $(p<0.05)$ decreased with the values in the range of 230.86 to 295.63 $\mathrm{mg} / 100 \mathrm{~g}$.

Low bioavailability of nutrients arising from the presence of antinutrients such as phytate, polyphenols, and oxalate, could limit the quality of predominantly plant-based diets. Uppal and Bains, (2012) ${ }^{[24]}$ reported that malting could significantly raise the bioavailability of nutrients. The tannin, phytate and oxalate contents of green gram malt flour decreased as the period of malting increased. The decrease observed in these parameters was significant $(p<0.05)$. However, a marginal increase in tannin content was observed in the 72 and $96 \mathrm{~h}$ malted samples. The decrease in phytate contents could be attributed to increased activity of phytase due to increase in malting periods that progressively degraded phytic acid.

Table 7: Total phenols and phytin phosphorus content of malted grains based supplementary foods

\begin{tabular}{|c|c|c|c|}
\hline Products & Samples & $\begin{array}{c}\text { Total Phenols } \\
(\mathbf{m g} \text { GAE/100g) }\end{array}$ & $\begin{array}{c}\text { Phytin Phosphorus } \\
(\mathbf{m g} / \mathbf{1 0 0 g})\end{array}$ \\
\hline Dalia & C1 & $249.38^{\mathrm{a}} \pm 0.005$ & $348.40^{\mathrm{a}} \pm 0.05$ \\
\hline & $\mathrm{C} 2$ & $260.72^{\mathrm{a}} \pm 0.05$ & $223.66^{\mathrm{c}} \pm 0.05$ \\
\hline & T1 & $292.82^{\mathrm{a}} \pm 57.73$ & $295.63^{\mathrm{b}} \pm 0.005$ \\
\hline Khichdi & $\mathrm{C} 1$ & $215.86^{\mathrm{c}} \pm 0.05$ & $283.63^{\mathrm{a}} \pm 0.05$ \\
\hline & $\mathrm{C} 2$ & $252.22^{\mathrm{b}} \pm 5.77$ & $209.27^{\mathrm{a}} \pm 57.73$ \\
\hline & T1 & $309.35^{\mathrm{a}} \pm 0.005$ & $235.65^{\mathrm{a}} \pm 57.73$ \\
\hline Panjiri & $\mathrm{C} 1$ & $249.86^{\mathrm{a}} \pm 0.05$ & $295.63^{\mathrm{a}} \pm 0.57$ \\
\hline & $\mathrm{C} 2$ & $259.30^{\mathrm{a}} \pm 57.73$ & $221.26^{\mathrm{c}} \pm 0.005$ \\
\hline & $\mathrm{T} 1$ & $273.46^{\mathrm{a}} \pm 0.05$ & $242.85^{\mathrm{b}} \pm 0.05$ \\
\hline Pancakes & $\mathrm{C} 1$ & $221.06^{\mathrm{a}} \pm 0.57$ & $288.43^{\mathrm{a}} \pm 57.73$ \\
\hline & $\mathrm{C} 2$ & $247.02^{\mathrm{a}} \pm 5.77$ & $206.87^{\mathrm{a}} \pm 0.05$ \\
\hline & $\mathrm{T} 2$ & $328.71^{\mathrm{a}} \pm 57.73$ & $250.05^{\mathrm{a}} \pm 0.005$ \\
\hline Seviyan & $\mathrm{C} 1$ & $252.69^{\mathrm{c}} \pm 0.05$ & $262.04^{\mathrm{a}} \pm 0.005$ \\
\hline & $\mathrm{C} 2$ & $268.74^{\mathrm{b}} \pm 0.005$ & $194.87^{\mathrm{c}} \pm 0.05$ \\
\hline & $\mathrm{T} 2$ & $279.13^{\mathrm{a}} \pm 0.05$ & $230.86^{\mathrm{b}} \pm 0.05$ \\
\hline
\end{tabular}

Values are expressed as Mean $\pm \mathrm{SE}$

Means with different notation $(\mathrm{a}, \mathrm{b}$ and $\mathrm{c}$ ) indicates significant difference at $5 \%$ level of significance. 


\section{Conclusion}

In this study, malted grains along with carrots and flaxseeds powder was found to have improved nutritional quality as compared to their raw samples. To overcome nutritional deficiency disorders, it is becoming compulsory that supplementary food should contain a staple as the main ingredient preferably a cereal, a protein source from legumes and pulses, a vitamin and mineral source from fruits or vegetable and an energy providing supplement such as oil/fat or sugar to increase the energy density of the supplementary food. Products developed from combination of cereals, pulse, oilseed and vegetable makes the foods nutrient dense and provides all the nutrients in appreciable amounts for the proper development and functioning of the body. When these ingredients used together in adequate proportions, they form a complete or balanced meal. These foods might be a better alternative of traditional foods for the growing children in improving their health and well-being.

\section{References}

1. Akeson WR, Stachman MA. A pepsin pancreatin digest index of protein quality evaluation. Journal of Nutrition. 1964; 83(3):257-261.

2. AOAC. Official methods of analysis, $17^{\text {th }}$ edn. The Association of Official Analytical Chemists. Washington, D.C, 2000.

3. Aziah AN, Noor AYM, Ho LH. Physico-chemical and organoleptic properties of cookies incorporated with legume flour. International Food Research Journal. 2012; 19(4):1539-1543.

4. Bala N, Verma A, Singh S. Development of low cost malted cereal and legume based nutritious weaning food to combat malnutrition in rural areas. International Journal of Food and Nutritional Sciences. 2014; 3(6):209-212.

5. Baranwal D. Malting: An indigenous technology used for improving the nutritional quality of grains - A review. Asian Journal of Dairy and Food Research. 2017; 36(3):179-183.

6. Booth VH. Problems in determination of FDNB available lysine. Journal of the Science of Food and Agriculture. 1971; 22(12):658-666.

7. Devi TA, Samundeeswari S. Effect of health mix supplementation on nutritional status of preschool girls. International Journal of Advanced Research. 2013; 1(3):26-32.

8. Ding J, Yang T, Feng H, Dong M, Slavin M. Enhancing contents of $\gamma$-aminobutyric acid (GABA) and other micronutrients in dehulled rice during germination under normoxic and hypoxic conditions. Journal of Agricultural and Food Chemistry. 2016; 64(5):1094-1102.

9. Dipnaik K, Bathere D. Effect of soaking and sprouting on protein content and transaminase activity in pulses. International Journal of Research in Medical Sciences. 2017; 5(10):4271-4276.

10. Haug W, Lantzsch HT. Sensitive method for rapid determination of phytate in cereals and cereal products. Journal of the Science of Food and Agriculture. 1983; 34(12):1423-1426.

11. Horn MJ, Jones DB, Blum AE. Colorimetric determination of methionine in proteins and foods. Journal of Biological Chemistry. 1946; 166(1):313-320.

12. Hung PV, Hatcher DW, Barker W. Phenolic acid composition of sprouted wheats by ultra-performance liquid chromatography (UPLC) and their antioxidant activities. Food Chemistry. 2011; 126(4):1896-1901.

13. Johnston R, Martin JM, Vetch JM, Shanks CB, Finnie S, Giroux MJ et al. Controlled sprouting in wheat increases quality and consumer acceptability of whole-wheat bread. Cereal Chemistry. 2019; 96(5):866-877.

14. Kavitha S, Parimalavalli R. Effect of processing methods on proximate composition of cereal and legume flours. Journal of Human Nutrition and Food Science. 2014; 2(6):1-5.

15. Kayembe NC, Rensburg CJV. Germination as a processing technique for soybeans in small-scale farming. South-African Journal of Animal Science. 2013; 43(2):167-173.

16. Nelson K, Stojanovska L, Vasiljevic T, Mathai M. Germinated grains: a superior whole grain functional food? Canadian Journal of Physiology and Pharmacology. 2013; 91(6):429-441.

17. Onwurafor EU, Uzodinma EO, Uchegbu NN, Ani JC, Umunnakwe IL, Ziegler G et al. Effect of malting periods on the nutrient composition, antinutrient content and pasting properties of mungbean flour. Journal of Tropical Agriculture, Food, Environment and Extension. 2020; 19(1):18-24.

18. Pasha I, Rashid S, Anjum FM, Sultan MT, Qayyum MMN, Saeed F et al. Quality evaluation of wheatmungbean flour blends and their utilization in baked products. Pakistan Journal of Nutrition. 2011; 10(4):388392.

19. Sadawarte SK, Pawar VS, Sawate AR, Thorat PP, Surendar J. Effect of germination on proximate and phytochemical content of horse gram and green gram malt. International Journal of Chemical Studies. 2018; 6(3):1840-1844

20. Singh AK, Rehal J, Kaur A, Jyot G. Enhancement of attributes of cereals by germination and fermentation: A Review. Critical Reviews in Food Science and Nutrition. 2015; 55(11):1575-1589.

21. Singh UK, Jambunathan R. Studies on desi and labuli chickpea (Cicer artimium L.) cultivars: The levels of amylase inhibitors, levels of oligosaccharides and in vitro starch digestibility. Journal of Food Science. 1982; 47(2):510-512.

22. Singleton VL, Orthofer R, Lamuela-raventos RM. Analysis of total phenols and other oxidation substrates and antioxidants by means of folin-ciocalteu reagent. Methods in Enzymology. 1999; 299(1):152-178.

23. Steve IO. Influence of germination and fermentation on chemical composition, protein quality and physical properties of wheat flour (Triticum aestivum). Journal of Cereals and Oilseeds. 2012; 3(3):35-47.

24. Uppal V, Bains K. Effect of germination periods and hydrothermal treatments on in vitro protein and starch digestibility of germinated legumes. Journal of Food Science and Technology. 2012; 49(2):184-191. 